\title{
The Summer 30 Royal Prank Call: \\ Outcomes for Australian Broadcasting Regulation
}

\section{Derek Wilding*}

On a Tuesday afternoon in December three years ago, two young presenters on the Australian radio programme Summer 30 devised a prank call to impersonate Queen Elizabeth and Prince Charles. The events that followed were soon known around the world. The station's licensee, Today FM (Sydney) Pty Ltd, tried to stop Australia's broadcasting regulator, the Australian Communications and Media Authority (ACMA), from finding it in beach of statutory and regulatory rules. But a recent unanimous decision of the High Court of Australia, reversing a unanimous decision of the Federal Court, has freed the ACMA to publish its investigation report and take enforcement action.

To the industry, the matter demonstrates severe regulatory overreach. To others, it exposes gaps in the industry codes of practice. Given the international interest in the subject, this note reports on the High Court's decision within the context of the ACMA's long-running investigation.

\section{INDUSTRY AND REGULATORY BACKGROUND}

Broadcasting in Australia is regulated almost exclusively under federal law. Licences for commercial radio services are issued by the ACMA under the Broadcasting Services Act 1992 (Cth) (BSA). The Act imposes conditions on these licences and establishes the framework for the industry to develop, and the ACMA to register, a code of practice. ${ }^{1}$ Matters that may be addressed by a code - for example, accuracy and fairness in news and current affairs and avoidance of indecent and harmful material - are included in an indicative list in s 123(2) of the Act. ${ }^{2}$ The ACMA can develop its own

\footnotetext{
* Visiting Fellow, Faculty of Law, University of Technology Sydney. All websites accessed 2 May 2015

${ }^{1}$ Commercial radio licences are allocated by the ACMA under Division 1 of Part 4 of the BSA. Standard licence conditions are imposed under Schedule 2. Codes of practice are registered under s 123.

${ }^{2}$ The ACMA is required by s $123(4)$ to register a code of practice if it is satisfied of three preconditions: it is endorsed by a majority of broadcasters in that section of the industry; there has been an adequate opportunity for
} 
programme standards if it considers there is convincing evidence that an industry code of practice is not operating to provide appropriate community safeguards. In the commercial radio sector, for example, the ACMA's standards dealing with disclosure of commercial agreements in current affairs programmes supplement a code provision on distinguishing advertising and programme material. ${ }^{3}$

As in other jurisdictions, the radio industry is multi-faceted. Commercial operators offer talk and music-based formats on generally high-powered services on the AM and FM bands. They are complemented by public service ('national') broadcasters and community-based services, as well as niche 'narrowcasting' services. ${ }^{4}$ All except the last category have allocations on the DAB+ multiplexes that serve the capital cities, but not regional areas.

Summer 30 was among the programmes offered by radio station 2Day FM, part of the Southern Cross Austereo group that controls radio and television stations around Australia. At the time of the prank call in late 2012, it was one of the most popular radio stations in Sydney, with a generally young demographic. ${ }^{5}$ The licensee was familiar with the ACMA's regulatory gaze: additional licence conditions had been imposed in response to breaches of the industry code of practice occurring in 2009 and $2011 .^{6}$

members of the public to comment on it; and it provides 'appropriate community safeguards' for the matters covered.

${ }^{3}$ See Broadcasting Services (Commercial Radio Current Affairs Disclosure) Standard 2012 and code 3.1 of the Commercial Radio Australia Codes of Practice and Guidelines 2013. The ACMA determines programme standards under s 125(1).

${ }^{4}$ The categories of broadcasting service are set out in Part 2 of the BSA.

${ }^{5}$ Summer 30 was cancelled by 2Day FM a week after the prank call. The station is now known as '2Day Hit 104.1'. In this commentary, 'Today FM' refers to the licensee of commercial radio licence 3032 while '2Day FM' refers to the radio station.

${ }^{6}$ See Investigation Report No. 2751 (22 November 2011) and Investigation Report No. 2266 (29 July 2009), available at www.acma.gov.au. Section 43 of the BSA gives the ACMA power to impose additional licence conditions. The most recent condition was imposed initially by the ACMA but amended by the Administrative Appeals Tribunal. See Today FM Sydney Pty Ltd v Australian Communications and Media Authority [2012] AATA 544. 


\section{THE PRANK}

The Duchess of Cambridge was admitted to the King Edward VII hospital in London with a condition associated with her pregnancy on Monday, 3 December 2012. The hospital visit attracted additional interest because it prompted an announcement that the Duchess was pregnant with her first child. She left the hospital three days later.

On the Tuesday afternoon (Australian time), two presenters with 2Day FM, Michael Christian and Mel Greig, recorded a segment for a programme they would host live that evening. Summer 30 was a variation of a regular programme broadcast on weekday evenings, with a mix of music, celebrities, movies, television and prizes. ${ }^{7}$ In the pre-recorded segment Christian and Greig discussed the prank then called the hospital at around $4.25 \mathrm{pm}$. The AMCA investigation report explains the call was established by the station's PAPX system, linked to the studio via an answering device known as Phone Box, then recorded and played out through equipment known as Voxpro.

It was about 5.25 am in London when the call was answered by nurse Jacintha Saldanha. Feigning an accent and representing herself as the Queen, Greig asked to be put through to the Duchess. Ms Saldanha transferred the call to a ward nurse who addressed Greig as 'ma'am' and provided information on the Duchess's condition. Christian contributed to the conversation, representing himself as Prince Charles. The transcript indicates the call ended without the prank being revealed, but in its submissions to the ACMA the licensee said five subsequent phone calls were made in an attempt to obtain consent prior to broadcast. The Summer 30 programme commenced at $7.30 \mathrm{pm}$ and the segment was broadcast at $9.04 \mathrm{pm}$. The broadcast attracted attention worldwide. Although the radio station and the presenters apologised after the prank received criticism, one of the presenters continued to promote the segment via Twitter. ${ }^{8}$

On the morning of Friday 7 December (UK time), Ms Saldanha was found dead in the nurses' quarters of the hospital. The Coroner, Dr Fiona Wilcox, later found Ms Saldanha took her own life. Dr Wilcox is reported to have said, 'I am satisfied that Jacintha Saldanha took her own life. At the time, the hoax was clearly pressing on her mind as were the difficulties she had been experiencing with her

\footnotetext{
${ }^{7}$ See ACMA Investigation Report No. 2928, p.2. The events of the afternoon of 4 December 2012 are related in the Summary of Facts at pp 21-22 of the report. The transcript of the segment is at Attachment A (pp 29-32).

${ }^{8}$ See p.12 of the Investigation Report.
} 
colleague. ${ }^{9}$ She is also reported to have said: 'This incident was not reasonably foreseeable. The support given was reasonable and appropriate.' In announcing it had donated an amount of $\operatorname{AUD} \$ 500,000(£ 289,000)$ to a trust fund for the benefit of her family, Southern Cross Austereo quoted the Coroner as saying 'There is no causation as a matter of law between the hoax call and any subsequent voluntary action by Ms Saldanha. ${ }^{10}$

On 1 February 2013, the Crown Prosecution Service for England and Wales issued a statement saying it had reviewed evidence supplied by the Metropolitan Police and had concluded that

'.. there is no evidence to support a charge of manslaughter and that although there is some evidence to warrant further investigation of offences under the Data Protection Act 1998, the Malicious Communications Act 1988 and the Communications Act 2003, no further investigation is required because any potential prosecution would not be in the public interest. $^{, 11}$

The CPS said it had reached this view after taking into account the fact that 'it is not possible to extradite individuals from Australia in respect of the potential offences in question' and that 'however misguided, the telephone call was intended as a harmless prank'. ${ }^{12}$

On 10 July 2013 the NSW Police Force recorded a holding statement indicating it and the Australian Federal Police (AFP) had received a referral from the Metropolitan Police and would investigate

\footnotetext{
${ }^{9}$ Caroline Davies, 'DJ apologises to Jacintha Saldanha's family as nurse's death ruled suicide' The Guardian (12 September 2014) http://www.theguardian.com/world/2014/sep/12/jacintha-saldanha-death-suicide-prank-call-djapologises; BBC 'Royal hoax phone call inquest: Nurse "took own life"' (12 September 2014) http://www.bbc.com/news/uk-29170543. Media reports are cited because a Coroner's report is not available.
}

${ }^{10}$ Media Release ‘Coronial Inquest - Jacintha Saldanha' (12 September 2014) http://www.southerncrossaustereo.com.au/media/2014/09/12/coronial-inquest-jacintha-saldanha/. Mel Greig also travelled to London to attend the inquest and apologise to Ms Saldanha's family.

11 'CPS decides no charges should be brought over the hoax calls to King Edward VII Hospital' (1 February 2013) http://www.cps.gov.uk/news/latest news/cps decides no charges should be brought over hoax calls to kin g edward vii hospital/.

${ }^{12}$ Ibid. 
whether any state offences could be identified. ${ }^{13}$ It was reported in September 2013 that the AFP had interviewed 2Day FM staff but no one had been arrested. ${ }^{14}$ Neither the NSW Police nor the AFP issued a statement on the outcome of their investigations; however, on 4 March 2015 (following the release of the decision of the High Court), several media outlets reported a statement from Southern Cross Austereo that it had been informed by both police agencies they had completed their investigations and found no breach of the Surveillance Devices Act 2007 (NSW) (SDA), the Telecommunications (Interception and Access) Act 1979 (Cth) (TIAA) or any other Act. ${ }^{15}$

\section{KEY EVENTS IN THE INVESTIGATION AND LEGAL ACTION}

On 13 December 2012, less than a week after Ms Saldanha's death, the ACMA notified Today FM that it had commenced an investigation under s 170 of the BSA. This section gives the ACMA a discretion to launch own-motion investigations, in contrast to s 149 under which it investigates complaints made first to the broadcaster. ${ }^{16}$ It invited the licensee to make submissions on whether (among other matters, described below) it had breached the licence condition imposed under $\mathrm{cl}$ $8(1)(g)$ in Schedule 2 to the BSA which prohibits the use of the broadcasting service in the commission of an offence under another Act. In essence, the question was whether recording and broadcasting without consent the conversations with the two nurses breached either the SDA or the TIAA.

\footnotetext{
${ }^{13}$ Advice to author from Media Unit, NSW Police Force, 30 April 2015. Fairfax Media was told by the Metropolitan Police it had referred the matter to the NSW Police and the AFP on 9 July 2013: Nick Miller, 'Scotland Yard calls for charges against royal hoax DJs' Sydney Morning Herald (11 July 2013) http://www.smh.com.au/world/scotland-yard-calls-for-charges-against-royal-hoax-djs-20130710-2pqs9.html.

${ }^{14}$ Ean Higgins, 'ACMA royal prank ruling could prejudice AFP probe' The Australian (19 September 2013) http://www.theaustralian.com.au/business/media/acma-royal-prank-ruling-could-prejudice-afp-probe-courttold/story-fna045gd-1226722830319.

${ }^{15}$ See, for example, the ABC report, 'London hospital prank: High Court backs authority's power to find 2Day FM radio presenters broke law' (4 March 2015) http://www.abc.net.au/news/2015-03-04/high-court-backs-acmaspower-to-find-2day-fm-broke-law/6279276. Although the statement has been cited by a number of sources, no official verification is available.

${ }^{16}$ A recent decision of the Federal Court confirmed aspects of the ACMA's powers in relation to s 170: Harbour Radio Pty Limited v Australian Communications and Media Authority [2015] FCA 371.
} 
Today FM made submissions in response on 2 January 2013, stating it was not open to the ACMA to make a finding that the relevant licence condition had been breached unless a court exercising criminal jurisdiction had first established that an offence under another Act had been committed. The ACMA rejected this interpretation of the BSA and on 4 June 2013 issued its Preliminary Investigation Report, giving the licensee the opportunity to comment on the proposed findings. The report found a breach of the licence condition and of parts of the Commercial Radio Australia Codes of Practice and Guidelines 2011 regarding the treatment of participants in 'live hosted entertainment programs' and the need to obtain consent before broadcasting the words of an identifiable person. ${ }^{17}$ Today FM responded to the ACMA on 18 June, the same day it filed an application for judicial review in the Federal Court of Australia, seeking declaratory relief on the limits of ACMA powers and injunctive relief to stop the regulator taking action on the basis of its findings.

On 7 November, Edmonds $\mathrm{J}$ found in the ACMA's favour and the ACMA then finalised its report on 20 February 2014. In the meantime, however, Today FM lodged an appeal with the Full Court of the Federal Court, which delivered its decision in favour of the licensee on 14 March 2014. On 15 August, the ACMA was granted special leave to appeal to the High Court, which heard the matter on 11 November and issued its decision in the ACMA's favour on 4 March 2015. After fulfilling the obligation under s 180 of the BSA to give the licensee an opportunity to make representations on the publication of matter which 'would or would be likely to adversely affect the interests of a person', the report was released on 20 April 2015.

\section{MATTERS UNDER INVESTIGATION}

The ACMA's investigation examines whether the licensee breached six obligations appearing variously in the Codes of Practice, the licence condition imposed on 2Day FM following earlier breaches of the Codes, and the standard licence condition set out in $\mathrm{cl} 8(1)(\mathrm{g})$ of Schedule 2 to the BSA.

\footnotetext{
${ }^{17}$ The 2011 version of the Codes of Practice, which was in operation at the time of the Summer 30 broadcast, was superseded by the current version in September 2013 but the two provisions examined here are unchanged. The code concerning participants in live hosted programs was developed in response to the ACMA's findings in an investigation prompted by 2Day FM's breach of the 'decency' code in 2009. See ACMA Investigation: Investigation into live hosted entertainment radio programs, January 2010.
} 
The obligations for which the ACMA found the licensee to be in breach are discussed below. In addition, the ACMA found there was no breach of the rule regarding offence against 'generally accepted standards of decency' (code 1.3(a)). As a result of this finding, the licensee did not breach the additional licence condition which required compliance with codes 1.3(a) and (b). Nor did it breach the rule concerning the use of 'material relating to a person's personal or private affairs, or which invades an individual's privacy' (codes 2.1(c) and (d)). The privacy rule only applies to news and current affairs programmes and the ACMA agreed with Today FM that Summer 30 was not such a programme.

At the outset, it is worth noting that enforcement powers given to the ACMA vary according to the rule that is breached. The regulator has a number of options in response to a breach of the licence condition in Schedule 2 to the BSA. It can issue a remedial direction, impose an additional licence condition, suspend or cancel the licence, seek a civil penalty order in the Federal Court, or refer the matter to the Director of Prosecutions for possible prosecution as an offence. All but the final two of these options are available for breach of an additional licence condition imposed by the ACMA under s 43. None of these options is available for breach of a code of practice - the ACMA must first impose an additional licence condition, then apply its enforcement powers if the additional condition is breached. Court-enforceable undertakings are also part of the regulatory regime and can apply in any of these situations, but they must be offered by a licensee and cannot be imposed by the ACMA. Despite improvements that flowed from additional powers in 2006, practical difficulties remain. ${ }^{18}$

\section{Broadcasting the words of an identifiable person}

The first of the two code provisions that the ACMA considered to be relevant reads as follows:

6.1 A licensee must not broadcast the words of an identifiable person unless:

(a) that person has been informed in advance or a reasonable person would be aware that the words may be broadcast; or

\footnotetext{
${ }^{18}$ The enforcement powers applying to commercial radio licences are found in the following sections of the BSA: s 43 additional licence condition; s 139(3) offence; s 140A(3) civil penalty; s 141(1) remedial directions; s 143(1) suspension and cancellation of the licence; s 205W(1) enforceable undertakings. The Communications Legislation Amendment (Enforcement Powers) Act 2006 (Cth) introduced remedial directions, civil penalties and enforceable undertakings.
} 
(b) in the case of words which have been recorded without the knowledge of the person, that person has subsequently, but prior to the broadcast, expressed consent to the broadcast of the words. ${ }^{19}$

Today FM did not dispute that the nurses were not informed in advance that the conversation might be broadcast, nor that consent was not obtained. Instead, it rejected the proposition that the nurses were identifiable persons. It said the rule could only be breached if audience members could identify the person concerned without making further inquiries, and said the information broadcast on Summer 30 would not allow Australian audiences to identify nurses at a London hospital without conducting further inquiries.

The ACMA rejected the argument that the scope of the code was limited to people in the local broadcast area of Sydney. It also said there was sufficient information to identify the nurses, given what was broadcast and what was already in the public domain. The Investigation Report appears to reject the argument that the test must be applied at the time of broadcast. It took account of the two nurses being 'predictably' identified by the hospital as a result of the prank and the licensee promoting the prank call after the event. ${ }^{20}$ It noted the content was likely to be highly newsworthy and it was likely to be detrimental to the two nurses.

\section{Participants in live hosted entertainment programs}

The second of the two code provisions relied on by ACMA reads:

9.1 Subject to Codes 9.2 to 9.3 below, a licensee must not broadcast a program which, in all of the circumstances:

(a) treats participants in live hosted entertainment programs in a highly demeaning or highly exploitative manner;

\footnotetext{
${ }^{19}$ For comments on possible inconsistencies between this code and the provisions of the SDA, see Anne Hyland, 'Radio prank call prompts code scrutiny' Australian Financial Review (12 December 2012) http://www.afr.com/business/media-and-marketing/radio/radio-prank-prompts-code-scrutiny-20121212-jifn9.

${ }^{20}$ Investigation Report p.12. The other aspects of this issue referred to above appear at pp 9-13 of the report.
} 
The clause also includes definitions of some key terms, some additional requirements relating to children, and some exemptions. ${ }^{21}$ Code 9.3 provides that a licensee will not breach the requirements, at least as far as adult participants are concerned, if 'the licensee informed the participant of the character of the relevant segment to be broadcast' and the participant consented prior to broadcast.

The ACMA rejected an argument from Today FM that the recording of the segment meant the nurses were not 'participants' in a 'live' program. In addition, as there was no content that was sexual in nature, the ACMA decided the segment was not highly demeaning. There was considerable discussion on the meaning of 'highly exploitative'. In concluding the broadcast was so exploitative, the ACMA said:

'... The broadcast used the deception of the prank to engage with the Employees in a way that was personally degrading and humiliating and was likely to reduce their professional standing.

'... Even if the material obtained as a result of the prank was unexpected, once it was obtained the decision to broadcast it - some four and a half hours after it was recorded - was made deliberately by the licensee and in circumstances in which the licensee could have assessed the likely impact of its broadcast on the Employees. ${ }^{22}$

\section{Offences under other Acts}

The full text of $\mathrm{cl} 8(1)(\mathrm{g})$ of Schedule 2 to the BSA is as follows:

8 Standard conditions of commercial radio broadcasting licences:

(1) Each commercial radio broadcasting licence is subject to the following conditions:

$[\ldots]$

(g) the licensee will not use the broadcasting service or services in the commission of an offence against another Act or a law of a State or Territory; ...

\footnotetext{
${ }^{21} \mathrm{~A}$ 'live hosted entertainment program' is one which is 'produced and broadcast live to air' and is a hybrid of various listed elements including a live host and, relevantly, 'pranks'. 'Demeaning' is defined as 'A depiction or description, sexual in nature, which is a serious debasement of the participant' while 'exploitative' is defined as 'Clearly appearing to purposefully debase or abuse the participant for the enjoyment of others, and lacking moral, artistic or other values'.

${ }^{22}$ Investigation Report p.17. This issue is set out in pp 13-18 of the report.
} 
This short clause prompted the legal challenge to the ACMA's powers. As noted above, a breach of this condition has far more serious consequences than a breach of a code of practice: it is open to the ACMA to suspend or cancel the licence.

The ACMA found there was no breach of the TIAA but that there was a breach of the SDA. In brief, the fact that communications from London to Sydney had completed their passage over a communications system by the time they had 'become accessible' and were recorded by the Voxpro system at the 2Day FM studio meant that the licensee's actions did not contravene the TIAA ${ }^{23}$. In contrast, the offence under the SDA is established where a 'listening device' is used (among other purposes) 'to record a private conversation to which the person is a party'. ${ }^{24} \mathrm{~A}$ further offence arises from publishing the private conversation recorded by the listening device ${ }^{25} \mathrm{~A}$ listening device is broadly defined to mean 'any device capable of being used to overhear, record, monitor or listen to a conversation or words spoken to or by any person in conversation .... A private conversation is (relevantly) 'any words spoken by one person to another person or to other persons in circumstances that may reasonably be taken to indicate that any of those persons desire the words to be listened to only ... by themselves ...26

The ACMA formed the view that Today FM had contravened ss 7(1) and 11(1) of the SDA and, because it had used its broadcasting service in the commission of an offence under the latter provision, it had breached the licence condition in $\mathrm{cl} 8(1)(\mathrm{g})$ of Schedule 2 to the BSA. ${ }^{27}$

\footnotetext{
${ }^{23}$ TIAA ss 5, 5F, 5G, 5H, 6, 7, 63 and 105.

${ }^{24}$ SDA s $7(1)(b)$.

${ }^{25}$ SDA s11(1).

${ }^{26}$ SDA s 4 . The factual aspects concerning the communications were agreed between the ACMA and Today FM and recorded in the Summary of Facts at pp 21-22 of the Investigation Report. The licensee's submissions and other aspects are set out at pp 20-28 of the report.

${ }^{27}$ In Investigation Report No. 2943 (1 October 2012) the ACMA considered the use of surveillance devices in a television news program but decided there was no breach of the SDA or of the applicable licence condition (cl $7(1)(h)$ to Schedule 2 of the BSA) because the recorded conversation was not a 'private conversation'. The use of listening devices in television current affairs programs was considered by the Supreme Court of New South Wales in relation to the since-repealed Listening Devices Act 1984 (NSW). See Miller v TCN Channel Nine (1988) 36 A Crim R 92, Director of Public Prosecutions (NSW) v Fordham [2010] NSWSC 795.
} 
The Investigation Report does not set out the licensee's arguments on the substantive issue of its breach of Ss 7(1) and 11(1) of the SDA, but it does record the arguments concerning the ACMA's powers (described below). It also mentions a further argument that the provisions of the SDA should be regarded as inoperative because they are in conflict with similar provisions of the TIAA. Today FM said the conflict was resolved by s 109 of the Australian Constitution with the effect that the TIAA will prevail over the SDA to the extent of the inconsistency. The ACMA rejected this argument on the basis that the TIAA does not purport to regulate circumstances where a conversation is recorded after a communication finishes passing over a telecommunications system. ${ }^{28}$ The issue was not raised by Today FM in its legal action.

\section{CHALLENGE TO ACMA POWERS}

On 18 June 2013, in response to the ACMA's Preliminary Investigation Report, Today FM applied to the Federal Court seeking a declaration as to the proper meaning of $\mathrm{cl} 8(1)(\mathrm{g})$ in conjunction with other relevant provisions ${ }^{29}$ and a declaration that the ACMA was not authorised to make the proposed findings concerning the SDA. As alternatives, Today FM sought orders that the relevant statutory provisions were invalid on Constitutional grounds and the preliminary findings of the ACMA were beyond power or invalid. ${ }^{30}$

Today FM also sought an injunction to stop the ACMA making a determination that the licensee had committed any criminal offence or even from 'forming, concluding or expressing any opinion' on the matter, as well as to stop the ACMA from preparing a final report to this effect. ${ }^{31}$

Edmunds $\mathrm{J}$ at first instance dismissed all of the arguments from Today FM and refused the application for declarations and injunctions. Set out below is the development of what His Honour referred to as the 'primary case' - the argument that the BSA and the ACMA Act do not, in the absence of a court

\footnotetext{
${ }^{28}$ See pp 25-26 of the report.

${ }^{29}$ These included the investigation and report making powers in ss 170 and 178 of the BSA as well as provisions in s 5 of the BSA and ss 10 and 12 of the Australian Communications and Media Authority Act 2005 (Cth) (ACMA Act) concerning the ACMA's role and functions in relation to broadcasting.

${ }^{30}$ Today FM (Sydney) Pty Ltd v Australian Communications and Media Authority [2013] FCA 1157 at pp 3-4.

${ }^{31}$ Ibid at pp 4-5.
} 
finding, authorise the ACMA to make findings that a licensee has committed an offence under another Act. $^{32}$

In brief, Edmunds $\mathrm{J}$ found that a decision by the ACMA of an offence under another Act is an administrative act and 'does not amount to the ACMA making a judgment as to the licensee's criminal guilt, still less determining an appropriate punishment for criminal guilt'. ${ }^{33}$

Reaching a different view, the Full Court of the Federal Court said administrative bodies cannot be empowered, at least without explicit statutory authorisation, to make findings on the commission of offences. The Full Court drew on a principle derived from an earlier decision (Lim), which it stated as follows:

'As a matter of general principle it is not normally to be expected that an administrative body such as the ACMA will determine whether or not particular conduct constitutes the commission of a relevant offence. It may be open to the legislature, subject to relevant constitutional constraints, to make clear that such a body is empowered to undertake that or a similar task. But under our legal system the determination of whether or not a person has committed a criminal offence can generally only be determined by a court exercising criminal jurisdiction. ${ }^{34}$

\footnotetext{
${ }^{32}$ A second argument, not considered in this commentary, was that the ACMA was in effect exercising a judicial power, contrary to requirements in Chapters II and III of the Constitution regarding the separation of judicial and executive powers. Today FM was unsuccessful in this argument at first instance and in the High Court; it was not considered by the Full Court of the Federal Court. A third argument about the potential for an ACMA investigation report to interfere with the administration of justice was dismissed at first instance and not pursued by Today FM. ${ }^{33}$ See n 30 at p.8.

${ }^{34}$ Today FM (Sydney) Pty Ltd v Australian Communications and Media Authority (2014) 218 FCR 461 at paragraph 76, citing Chu Kheng Lim v Minister for Immigration, Local Government and Ethnic Affairs (1992) 176 CLR 1 at 27. The Full Court's statement of this principle had wider application to the activities of other State and Commonwealth administrative bodies, with the result that the Attorneys-General for Queensland, South Australia, Western Australia and the Commonwealth intervened in the High Court.
} 
The High Court, however, agreed with the ACMA that this was too wide a statement of the principle expressed in Lim, and accordingly, '[i]t was an error to construe $\mathrm{cl} 8(1)(\mathrm{g})$ in the light of the posited principle. ${ }^{35}$ The plurality (French CJ with Hayne, Kiefel, Bell and Keane JJ) noted 'Not uncommonly, courts exercising civil jurisdiction are required to determine facts which establish that a person has committed a crime. Satisfaction in such a case is upon the balance of probabilities. ${ }^{, 36}$ The High Court's approach, and the implications for administrative bodies under Australian law, is clearly evident from the example offered in the plurality judgment:

'... it is not offensive to principle that an administrative body is empowered to determine whether a person has engaged in conduct that constitutes a criminal offence as a step in the decision to take disciplinary or other action... There is no reason to suppose that a Commonwealth public housing authority might lack the capacity to terminate a lease on the ground of the tenant's use of the premises for an unlawful purpose notwithstanding that the tenant has not been convicted of an offence arising out of that unlawful use. ${ }^{37}$

In distinguishing an earlier case involving the Independent Commission Against Corruption (ICAC), an authority established under statute in New South Wales, the High Court noted significant differences between the ICAC (which is an investigative body) and the ACMA (which regulates broadcasting services generally and has its own enforcement powers). ${ }^{38}$ It also noted that risks that might arise from publication of investigation findings are directly addressed in the BSA, in that s 179(3) allows for reports to be confidential (including where there may be a risk to a fair trial) and s 180 requires the

\footnotetext{
${ }^{35}$ Australian Communications and Media Authority v Today FM (Sydney) Pty Ltd [2015] HCA 7 at 13 and 15.

${ }^{36}$ Ibid at 13-14. A series of cases dating from Helton v Allen (1940) 63 CLR 691 was cited in support of the first aspect, with Hocking v Bell (1945) 71 CLR 430 and Rejfek v McElroy (1965) 112 CLR 517 in support of the second aspect.

${ }^{37}$ Ibid at 14. Their Honours noted Attorney-General (Cth) v Alinta Ltd (2008) 233 CLR 542 at 576 and Albarran v Companies Auditors and Liquidators Disciplinary Board (2007) 231 CLR 350 at 361 in support of the proposition that such a power is not 'offensive to principle'.

${ }^{38}$ See n 35 at 16-17, referring to Balog v Independent Commission Against Corruption (1990) 169 CLR 625.
} 
ACMA to give a person whose interests may be adversely affected an opportunity to comment before publishing a report. ${ }^{39}$

The plurality also noted the significant constraint on the ACMA's enforcement powers that would arise if required to wait until a different court had ruled on the offence - something that was not supported by the text of $\mathrm{cl} 8(1)(\mathrm{g})$ nor the associated provisions of the BSA. ${ }^{40}$ Their Honours noted that Today FM's reasoning would mean that a criminal court considering an action by the Director of Public Prosecutions under s 139(3) of the BSA, or a civil court considering an application by the ACMA for a civil penalty order under s 140A(3), would similarly be stopped from making a decision unless another court had first found an offence was committed. ${ }^{41}$

The implications for the ACMA were spelled out by Gageler $\mathrm{J}$ in his separate reasons. His Honour said the Full Court's approach 'would make compliance or non-compliance with the norm of conduct specified by the clause incapable of contemporaneous objective determination' because it would be contingent on another Commonwealth, State or Territory agency deciding to prosecute, and on the subsequent conviction. ${ }^{42} \mathrm{He}$ said, 'Pending prosecution and conviction for the offence, the Authority could not even direct the licensee to take remedial action to ensure that the conduct constituting the commission of the offence did not continue or recur. ${ }^{43}$

In the end, the Court unanimously agreed with Edmunds $\mathrm{J}$ and held that in finding a licensee had breached $\mathrm{cl} 8(1)(\mathrm{g})$, the ACMA would not be 'adjudging and punishing criminal guilt' and there was no requirement that a criminal court had already found an offence before the ACMA could investigate a possible breach under that clause, issue a report and take enforcement action. ${ }^{44}$

\section{WHAT REMAINS}

As is evident from the outline of events above and the nature of the High Court's findings, the ACMA's investigation is not at an end - in fact, there may be more legal action before the matter is concluded.

\footnotetext{
${ }^{39}$ Ibid at 17.

${ }^{40}$ Ibid at 18.

${ }^{41}$ Ibid at 17.

42 Ibid at 28.

${ }^{43}$ Ibid.

${ }^{44}$ See the plurality judgment at p.19.
} 
To date, the ACMA has progressed the investigation to the point of publishing its report and indicating in an accompanying media release that it 'will now move formally to consider what sanctions should apply'. ${ }^{45}$ There has been speculation in the Australian media that the ACMA could impose a short suspension of the licence under s 143(1)(c), noting that a suspension of even a few hours would have a substantial impact on the licensee, given the loss of advertising. ${ }^{46}$

A decision to suspend the licence could be subject to separate proceedings for judicial review. In addition, while only a very limited number of decisions made by the ACMA under the BSA are subject to merits review by the Administrative Appeals Tribunal, ${ }^{47}$ suspension or cancellation of a licence is among these. As the ACMA has never suspended or cancelled a commercial broadcasting licence, the power is untested, but should Today FM seek review in the AAT, many of the issues in the investigation would be considered afresh.

\section{IMPLICATIONS}

For broadcasting law and regulation in Australia, the Today FM matter is important in clarifying when a broadcasting regulator can take enforcement action. Interestingly, it shows the ACMA acting under broadcasting law in relation to an impact on people in another jurisdiction. But it also reveals deficiencies in the codes of practice applying to commercial radio in Australia.

\footnotetext{
45 Media Release 19/2015 'ACMA publishes “Royal Prank Call” investigation report' (22 April 2015) http://www.acma.gov.au/Industry/Broadcast/Radio/Radio-content-regulation/acma-publishes-royal-prank-call-
} investigation-report. In an interview after the High Court decision, the ACMA Chairman, Chris Chapman, ruled out cancellation of the licence. See 'ACMA, Austereo and the High Court' The Media Report ABC Radio National (5 March 2015) http://www.abc.net.au/radionational/programs/mediareport/acma2c-austereo-and-the-highcourt/6282746.

${ }^{46}$ See for example: Michael Bodey, 'ACMA could take TodayFM off air after court ruling over royal prank' The Australian (4 March 2015) http://www.theaustralian.com.au/business/media/acma-could-take-todayfm-off-airafter-court-ruling-over-royal-prank/story-e6frg996-1227247536106; 'ACMA, Austereo and the High Court', n 45; Nic Christensen, 'ACMA chair refuses to rule out suspending 2DayFM's licence over royal prank call' mumbrella (Sydney, 6 March 2015) http://mumbrella.com.au/acma-chair-2dayfm-decision-279751.

${ }^{47}$ These decisions are listed in a table in s 204 of the BSA. Other decisions are still subject to judicial review. 


\section{Regulator's powers}

The outcome of Today FM's challenge to the ACMA has been lamented by the free-to-air and subscription broadcasting sectors of the industry, with calls for amendments to the BSA. Commercial Radio Australia said 'the ACMA can now act as police, judge and jury'. Free TV Australia said the decision highlights a 'serious flaw in the law'. ${ }^{48}$ The Chief Executive of the Australian Subscription Television and Radio Association (ASTRA) said 'This constitutes a significant and material expansion of ACMA's role, far outside its expertise as the administrative body that oversees communications regulation'. ${ }^{49}$

Is the ACMA really acting as police, judge and jury? The High Court was resolute in its finding that the ACMA's view on whether an offence has been committed under another Act - for the purpose of determining a breach of broadcasting law - will have no bearing on action by a State, Territory or Federal authority. Even on the question of whether the ACMA's findings prejudice the licensee's interests when seeking judicial review of a decision to suspend or cancel a licence, the ACMA's view - in the words of Gageler J - 'would bind no one and conclude nothing'. ${ }^{50}$

This leaves the question of whether it is desirable for the ACMA to be able to suspend or cancel a licence which it has, itself, issued after forming a view that an offence under the SDA was committed - even if that view would have no effect on any prosecution by the NSW police.

\footnotetext{
${ }^{48}$ Media Release 'High Court Ruling has ramifications for entire broadcast industry' (4 March 2015) http://www.commercialradio.com.au/content/mediareleases/2015/2015-03-04-high-court-ruling-has-ramificationsfor\#.VURglEYx6Hk; Media Release, 'Free TV calls on government to amend the Broadcasting Services Act' (4 March 2015) http://www.freetv.com.au/media/News-

Media Release/Free TV Media Statement FREE TV CALLS ON GOVERNMENT TO AMEND THE BSA.p df. Commercial Radio Australia (CRA) and Free TV Australia are member-based organisations, representing almost all commercial radio and commercial television broadcasters in Australia. As CRA has developed the code of practice for commercial radio, Free TV has developed the Commercial Television Industry Codes of Practice 2010.

${ }^{49}$ AAP, 'Broadcaster slams royals prank call ruling' The Australian (4 March 2015) http://www.theaustralian.com.au/business/latest/broadcaster-slams-royals-prank-call-ruling/story-e6frg90f1227248199421.

${ }^{50} \mathrm{~N} 35$ at 31.
} 
In discussing the way in which, on the interpretation of the BSA adopted by Today FM, the ACMA would be unable to act on current breaches, Gageler J noted that the words 'commission of an offence' in cl 8(1)(g) could be 'read as referring to the doing of acts which constitute the commission of an offence'. ${ }^{51}$ If an ACMA finding on offences committed under the SDA does not establish criminal guilt, the finding is, in effect, a decision that the rules against recording and broadcasting private conversations without consent have been contravened.

The comment above shows that ASTRA, at least, thinks the ACMA is not competent to make such a decision. However, given the ACMA is a converged regulator with responsibilities for broadcasting, telecommunications, radiocommunications and online services and with extensive powers of investigation including document production and oral examinations $s^{52}-$ it is hard to imagine a case where the ACMA is more competent to judge whether rules have been contravened. ${ }^{53}$

\section{Radio standards}

Perhaps more important than the question of the regulator's powers is what the investigation has shown about standards of practice applying to commercial radio in Australia. The conduct most clearly open to regulatory review is not the attempt by two presenters to speak to a Duchess; it is the decision of their producers to broadcast the segment four and a half hours later, knowing all attempts to obtain consent had failed. The radio station apparently believed it was free to record, unknown to the participants, a conversation that could have damaging effects on them, and then broadcast it without consent.

It might be expected that the code of practice would have clear rules preventing such conduct, but the investigation shows there is in fact a patchwork of provisions. Today FM's arguments to the ACMA about why the prank call did not breach the applicable codes of practice were made after the event and might not represent its views generally on how to ensure compliance with them. However, it is worth noting that Today FM argued the two provisions on which the ACMA found a breach did not

\footnotetext{
${ }^{51}$ Ibid at 28.

${ }^{52}$ The investigation powers in s 177 and ss 173-176 were noted by Edmonds $\mathrm{J}(\mathrm{p} .8)$ in finding that the ACMA may conduct an investigation itself as to commission of an offence, and not await the findings of a court.

${ }^{53}$ In considering other laws that might affect a broadcasting licensee company, the ACMA would be able to call on extensive experience in considering complex financial and commercial arrangements.
} 
apply to content of this kind: it said no individuals were identifiable to local audiences (for the purposes of code 6) and the segment was not live (for the purposes of code 9).

The investigation shows that the slim terms of codes 6 and 9 have a lot work to do in safeguarding the interests of participants in radio programmes. It also exposes the narrow scope of the privacy protections. While the information broadcast about the Duchess's health was not at issue here, the case shows there is no explicit privacy provision that applies to programmes like Summer 30 - or any type of programme apart from news and current affairs.

It is worth noting here that broadcasters, as organisations involved in news and current affairs, are exempt from statutory obligations on the gathering and handling of personal information when they are conducting activities 'in the course of journalism'. ${ }^{54}$ The exemption only applies if the broadcaster is 'publicly committed to observe standards' dealing with privacy that are published by the broadcaster or a representative body. The applicable standards for 2Day FM are the Commercial Radio Australia Codes of Practice, but programmes such as Summer 30 are exempt from the privacy obligations because they are not news or current affairs programmes.

While the decision of the High Court settled a point of uncertainty in the scope of ACMA's powers under the BSA, the regulator's investigation has revealed significant deficiencies in the 'community safeguards' meant to operate under industry codes.

\footnotetext{
${ }^{54}$ Privacy Act 1988 (Cth) s 7B(4). 'Journalism' is not defined. For an analysis of this issue, see the Australian Law Reform Commission report, For Your Information: Australian privacy law and practice (ARLC Report 108, August 2008), especially Recommendation 42-1, p.1452.
} 